University of Nebraska - Lincoln

DigitalCommons@University of Nebraska - Lincoln

USDA National Wildlife Research Center - Staff Publications
U.S. Department of Agriculture: Animal and Plant Health Inspection Service

January 2005

\title{
The Impact of Disease in the American White Pelican in North America
}

Tonie Rocke

USGS National Wildlife Health Center

Kathryn Converse

USGS National Wildlife Health Center

Carol Meteyer

USGS National Wildlife Health Center

Bob McLean

USGS National Wildlife Health Center, USDA/APHIS/WS National Wildlife Research Center

Follow this and additional works at: https://digitalcommons.unl.edu/icwdm_usdanwrc

Part of the Environmental Sciences Commons

Rocke, Tonie; Converse, Kathryn; Meteyer, Carol; and McLean, Bob, "The Impact of Disease in the American White Pelican in North America" (2005). USDA National Wildlife Research Center - Staff Publications. 49.

https://digitalcommons.unl.edu/icwdm_usdanwrc/49

This Article is brought to you for free and open access by the U.S. Department of Agriculture: Animal and Plant Health Inspection Service at DigitalCommons@University of Nebraska - Lincoln. It has been accepted for inclusion in USDA National Wildlife Research Center - Staff Publications by an authorized administrator of DigitalCommons@University of Nebraska - Lincoln. 


\title{
The Impact of Disease in the American White Pelican in North America
}

\author{
Tonie Rocke ${ }^{1}$, Kathryn Converse $^{1}$, CARol Meteyer $^{1}$ And Bob MCLEaN $^{1,2}$ \\ ${ }^{1}$ USGS National Wildlife Health Center, 6006 Schroeder Road, Madison, WI 53711, USA \\ Internet: tonie_rocke@usgs.gov
}

${ }^{2}$ Current address: National Wildlife Research Center, Wildlife Services, Animal Plant Health Inspection Service U.S. Department of Agriculture, 4101 Laporte Avenue, Fort Collins, CO 80521-2154

\begin{abstract}
Records of reported die-offs of the American White Pelican (Pelicanus erythrorhynchos) held by the U.S. Geological Survey National Wildlife Health Center from 1978 through 2003 indicate that type C botulism (caused by Clostridium botulinum) was the major cause of mortality. In 1996, over 15,000 birds, including 8,500 American White Pelicans, were estimated to have died from type C botulism at the Salton Sea in California. This was the largest documented die-off of any pelican species and was estimated to represent $15-20 \%$ of the western metapopulation. This event was also notable in that it was the first time that fish, specifically Tilapia (Oreochromis mossambicus), were implicated as the source of type $\mathrm{C}$ botulinum toxin for birds. Type $\mathrm{C}$ botulism has recurred in both North American species of pelicans at the Salton Sea every year since, although the magnitude of mortality is much lower. West Nile virus caused mortality in both adult and immature American White Pelicans, but may have a more significant impact on nestlings. Emaciation and mortality is common in pelican nesting colonies. Further clarification of the cause of nestling mortality and the ability to differentiate background mortality from mortality due to infectious disease agents such as West Nile virus and Newcastle disease virus would be important in determining the impact of disease in pelicans. Although definitive conclusions cannot be drawn, the number of die-offs and the estimated losses of American White Pelicans appears to have increased along with declines in number in western U.S.
\end{abstract}

Key words.-American White Pelican, avian botulism, disease, Newcastle disease, West Nile Virus, Pelicanus erythrorhynchos.

Waterbirds 28 (Special Publication 1): 87-94, 2005

The American White Pelican (Pelicanus erythrorhynchos) is one of two pelican species that breed in North America. Numbers of the American White Pelican (AWPE) east of the continental divide have increased in recent years due largely to wetlands protection and the availability of winter food from aquaculture operations (King 2005). However, the western metapopulation of AWPE is lower than historical numbers (Anderson and King 2005). Numerous factors could be responsible for this regional decline, including habitat loss and poor juvenile recruitment, but catastrophic mortality from disease has been implicated as a contributor at certain locations. In 1996, a large epizootic of type C avian botulism occurred at the Salton Sea in southern California killing nearly 15,000 birds; over half of those killed were AWPE (Friend 2002; Rocke et al. 2004). The die-off at Salton Sea was the largest ever recorded in any species of pelican and represented an estimated $15-20 \%$ of the western metapopulation (D. W. Anderson, pers. comm.).

In an effort to evaluate the causes and potential impact of disease and other mortality factors in AWPE in North America, we reviewed and summarized over 25 years of dieoff data involving AWPE that were reported to the U.S. Geological Survey, National Wildlife Health Center (NWHC). Due to the difficulty in estimating mortality in birds and the nonrandom nature of carcass collection and submission to diagnostic laboratories, this summary does not necessarily reflect the actual proportional distribution of mortality factors. However, the findings identify the major disease agents and mortality factors that occur in AWPE and that could potentially have an impact on numbers.

\section{METHODS}

Data were reviewed and summarized from 183 dieoffs that included AWPE recorded in the NWHC epizootic database from 1978 through 2003 (Table 1). The NWHC is a U.S. Department of the Interior facility that provides diagnostic services to natural resource managers throughout the United States and its territories and also compiles data on epizootics that are reported by federal, state and other personnel. Reports of AWPE mortality were submitted from 22 states and Canada involving all four migratory bird flyways.

Cause of death determinations during die-offs were based on submission of several representative carcasses, 
mostly of birds found dead, but sick birds (euthanized) were obtained whenever possible. A gross examination, including a description of wounds and abnormalities and an evaluation of overall body condition with respect to fat reserves and pectoral muscular development, was conducted on each carcass. Samples of organs were tested for a variety of microbes, parasites, and toxins as indicated by gross findings and field information provided by the submitter. Tissues for histopathology were fixed in $10 \%$ buffered formalin, embedded in paraffin, sectioned for light microscopy and stained with hematoxylin and eosin for routine microscopic examination, Ziehl-Neelsen acid-fast for mycobacteria, Grocott silver for fungi, and Giminez stain for chlamydia-like organisms. Bacteria were isolated by inoculation of tissues onto $5 \%$ sheep red-blood agar and eosin-methylene blue plates (DIFCO laboratories, Detroit, Michigan, U.S.A.), incubated at $37^{\circ} \mathrm{C}$ for $72 \mathrm{~h}$, and then characterized with the API-20E system (Analytab Products, Plainview, New York). Tissues for virus isolation attempts were processed according to Docherty and Slota (1988) and Senne (1989). Polymerase chain reaction assays (Vita-Tech Laboratories, Markham, Ontario, Canada) were used for detection of chlamydia DNA and isolation attempts for Chlamydia psitacci were performed by the Wisconsin Animal Health Laboratory (Madison, Wisconsin).

The presence of botulinum toxin in heart blood was evaluated using either the mouse neutralization test (Quortrup and Sudheimer 1943) or the enzyme-linked immunsorbent assay (Rocke et al. 1998). Botulinum toxin was identified to type using specific antisera. Because of the possibility of post-mortem botulinum toxin formation in carcasses, a diagnosis of botulism depended on observation of clinical signs in birds characteristic of botulism (limb paralysis, limberneck, paralysis of the nictitating membrane), the absence of obvious lesions upon necropsy and histologic examination of tissues, as well as confirmation of toxin in the blood of live birds or dead birds with minimal autolytic change. Suspected botulism was recorded as the diagnosis if toxin could not be demonstrated in the blood, but clinical signs characteristic of botulism were observed, other birds from the site were confirmed to have died of botulism, and no lesions were noted either grossly or histologically that would suggest another cause of death.

West Nile virus encephalitis was considered the cause of death if virus was isolated from tissues and lesions consistent with West Nile virus were present. West Nile virus encephalitis was suspected if lesions in the central nervous system consistent with West Nile viral infection were present, but no virus was isolated.

Several analyses were performed for the detection of chemical contaminants. When exposure to organophosphorus or carbamate agricultural pesticides was suspected, brains were screened for cholinesterase activity. Cholinesterase assays were performed according to Ellman et al. (1961) and later modified by Dieter and Ludke (1975) and Hill and Fleming (1982), including incubation $\left(18 \mathrm{~h}\right.$ at $\left.37^{\circ} \mathrm{C}\right)$ and retesting of samples with initially low enzyme activities to look for enzyme reactivation that would help to differentiate between a carbamate and an organophosphate. Cholinesterase inhibition was calculated by comparison with normal published values (Hill 1988) or control values determined by the NWHC (Smith et al. 1995). In most cases where inhibition of brain cholinesterase activity was noted, stomach contents were analyzed at the Patuxent Wildlife Research Center, Laurel, Maryland for 24 orga- nophosphorus and six carbamate compounds, according to Belisle and Swineford (1988). Brains were analyzed for residues of chlorinated hydrocarbons by gas-liquid chromatography (Cromartie et al. 1975; Blus et al. 1989), liver lead residues were determined according to Boyer (1984) and methods for selenium analysis of liver followed Krynitsky (1987). The diagnoses for poisoning due to dieldrin, endrin and chlordane (measured as oxychlordane residue) was made when the brain wet-weight residues of these compounds exceeded $4.0 \mathrm{ppm}, 0.7 \mathrm{ppm}$ and $5.8 \mathrm{ppm}$, respectively (Stickel et al. 1969; Stickel et al. 1979a; Stickel et al. 1979b).

\section{RESULTS AND DISCUSSION}

\section{General Findings}

Definitive conclusions about AWPE mortality cannot be made because the NWHC epizootic database is based on submitted reports of events by numerous individuals and the data are not systematically collected. Nevertheless, several general trends are evident and of interest. Of the 183 die-offs reviewed that included the AWPE, 93 reports involved the loss of ten or more birds and are summarized in Tables 1, 2 and 3. Causes of death in AWPE in these 93 reports included avian cholera, aspergillosis, botulism (type C, E, and suspect), chlamydiosis (suspect), emaciation of unknown etiology, possible Newcastle disease, trauma (hailstorm, gunshot, powerline strike), toxicoses (organochlorine pesticides) and West Nile virus encephalitis. Die-offs where the cause of death was undetermined, but emaciation was apparent in birds examined, were included in the category "emaciation of unknown etiology".

Table 1. Records of American White Pelican mortality in the U.S. Geological Survey, National Wildlife Health Center epizootic database from 1978-2003.

\begin{tabular}{lccc}
\hline \hline Years & $\begin{array}{c}\text { Total } \\
\text { number } \\
\text { of records }\end{array}$ & $\begin{array}{c}\text { Number of die- Estimated loss- } \\
\text { offs with over } \\
\text { ten deaths }\end{array}$ & $\begin{array}{c}\text { es from report- } \\
\text { ed die-offs }\end{array}$ \\
\hline $1978-1981$ & 10 & 3 & 55 \\
$1982-1985$ & 15 & 5 & 264 \\
$1986-1989$ & 20 & 11 & 812 \\
$1990-1993$ & 38 & 23 & 10,963 \\
$1994-1997$ & 32 & 13 & 9,568 \\
$1998-2001$ & 35 & 20 & 3,996 \\
$2002-2003$ & 31 & 18 & 9,905 \\
Total & 181 & 93 & 35,563 \\
\hline
\end{tabular}


Table 2. Cause of death and number of die-offs that involved mortality of more than ten American White Pelicans as reported to the U.S. Geologic Survey, National Wildlife Health Center, 1978-2003.

\begin{tabular}{lcr}
\hline \hline Etiology & $\begin{array}{c}\text { Number } \\
\text { die-offs }\end{array}$ & $\begin{array}{r}\text { Estimated } \\
\text { mortality }\end{array}$ \\
\hline Type C botulism $^{1}$ & 44 & 11,588 \\
West Nile virus $^{2}$ & 11 & 9,322 \\
Emaciation $^{\text {Possible Newcastle disease }}{ }^{3}$ & 11 & 5,898 \\
Trauma $^{4}$ & 5 & 5,206 \\
Toxicosis $^{5}$ & 7 & 1,817 \\
Avian cholera $_{\text {Chlamydiosis }}{ }^{6}$ & 1 & 1,000 \\
Aspergillosis & 4 & 132 \\
Undetermined $^{2}$ & 1 & 120 \\
\hline
\end{tabular}

${ }^{1}$ Includes four die-offs in which botulism was suspected as the cause of death, based on clinical signs.

${ }^{2}$ Includes one die-off in which virus was not isolated but was suspected, based on histopathologic lesions of the central nervous system consistent with West Nile virus encephalitis in pelicans that were sick and euthanized. Also, includes one die-off in which type $\mathrm{C}$ botulism was also diagnosed in pelicans that were sick and euthanized.

${ }^{3}$ Newcastle disease was the cause of mortality in five Double-crested Cormorant colonies with concurrent mortality of undetermined cause in $>5,000$ AWPE on the same islands in 1992. Clinical signs in juvenile AWPE, similar to those reported in the Double-crested Cormorant, were observed, although the virus was not isolated from 24 AWPE carcasses examined.

${ }^{4}$ Includes trauma from hailstorms, powerline strikes and gunshot.

${ }^{5}$ Organochlorine pesticides (dieldrin, endrin and chlordane)

${ }^{6}$ Chlamydia psitacci was suspected as the cause of death due to gross lesions observed and positive polymerase chain reaction results, although the bacteria could not be isolated.

Type $\mathrm{C}$ botulism was by far the most reported cause of death in the AWPE, with 44 epizootics and an estimated loss of 11,588 birds in ten states (California, Florida, Kansas, Minnesota, Montana, Nevada, North Dakota, Oregon, South Dakota, and Utah) since 1980 (Table 2, Fig. 1). West Nile virus was considered the cause of mortality in excess of 9,000 birds in seven states (Iowa, Kansas, Minnesota, Missouri, Montana, North Dakota, and South Dakota) in 2002 and 2003. Emaciation of unknown etiology was next, with an estimated loss of 6,000 birds, mostly juveniles in breeding colonies. Newcastle disease was the cause of mortality in five Double-crested Cormorant (Phalacroco- rax auritus) breeding colonies with concurrent mortality of undetermined cause in AWPE on the same islands. Estimated losses of 5,000 AWPE in three states (Minnesota, North Dakota, South Dakota) in 1992 and mortality of 140 AWPE in the central Canadian prairies in 1990 were reported in association with these Newcastle disease epornitics in Double-crested Cormorants.

On a geographic basis (Fig. 1), type C botulism was the greatest disease-causing agent in states in the Pacific flyway and was also important in the Central flyway, but not significant in the Atlantic or Mississippi flyways. West Nile virus encephalitis cases occurred in breeding colonies in the Mississippi and Central flyways, but not in the Pacific flyway. Since its introduction into eastern U.S. in 1999, the disease has steadily spread westward (Komar 2003) and may afflict AWPE breeding colonies in the Pacific flyway metapopulation in the near future.

Notably, both the total number of die-offs and the number of die-offs involving more than ten AWPE individuals (Table 1) increased approximately three-fold between the first twelve-year period (1978-1989) and the second twelve-year period (1990-2001) that were included in this summary. Even more dramatic was the increase in estimated total mortality from less than 1,200 AWPE prior to 1990 to nearly 25,000 from 1990-2001. Furthermore, in the last two years alone (2002-2003), 35 die-offs (with more than ten individuals) have been reported with estimated losses of over 10,000 AWPE. Several factors may account for these observations. Part of the increase could be attributed to better surveillance and reporting. The number of reported die-offs for all bird species in the NWHC database increased from an average of 134 year $^{-1}$ between 1978-1989 to an average of 186 year $^{-1}$ between 1990-2001 (NWHC unpublished data). However, it is unlikely that this explanation would fully account for the increase in reported AWPE mortalities from an average of 60 per event prior to 1990 to an average of 467 per event after 1990.

Another possibility for the observed increase in total mortality is the occurrence of emerging diseases, defined as either a newly 
Table 3. Cause of death and estimated magnitude of losses in the American White Pelican by flyway, as reported to the U.S. Geological Survey, National Wildlife Health Center, 1978-2003.

\begin{tabular}{|c|c|c|c|c|c|}
\hline \multirow[b]{2}{*}{ Flyway } & \multirow[b]{2}{*}{ Etiology } & \multicolumn{3}{|c|}{ Number of die-offs with losses } & \multirow{2}{*}{$\begin{array}{c}\text { Total loss } \\
>5000\end{array}$} \\
\hline & & $10-100$ & $100-1000$ & $1000-5000$ & \\
\hline \multirow[t]{3}{*}{ Atlantic } & Toxicosis & & & 1 & 1,000 \\
\hline & Aspergillosis & 1 & & & 24 \\
\hline & Type C botulism & 1 & & & 16 \\
\hline \multirow{6}{*}{ Mississippi } & West Nile virus & 2 & & 2 & 5,464 \\
\hline & Possible Newcastle disease & & & 1 & 1,960 \\
\hline & Emaciation & & 1 & & 200 \\
\hline & Undetermined & 3 & & & 63 \\
\hline & Type C botulism & 1 & & & 50 \\
\hline & Trauma & 1 & & & 35 \\
\hline \multirow{7}{*}{ Central } & Emaciation & 4 & 1 & 1 & 5,188 \\
\hline & West Nile virus & 3 & 3 & 1 & 3,858 \\
\hline & Possible Newcastle disease & 1 & 2 & 1 & 3,246 \\
\hline & Trauma & 4 & & 1 & 1,762 \\
\hline & Type C botulism & 24 & 3 & & 1,543 \\
\hline & Chlamydiosis & & 1 & & 120 \\
\hline & Undetermined & 4 & 1 & & 393 \\
\hline \multirow[t]{4}{*}{ Pacific } & Type C botulism & 12 & 2 & 1 & 9,979 \\
\hline & Emaciation & 3 & 1 & & 510 \\
\hline & Avian cholera & 4 & & & 132 \\
\hline & Trauma & 1 & & & 20 \\
\hline
\end{tabular}

recognized disease agent or the novel appearance of a previously recognized disease (Friend et al. 2001). All the die-offs with AWPE mortality of 1,000 individuals or greater (Table 3) occurred between 1990 and 2003, and several new diseases were recognized during this time period, including chlamydiosis, West Nile virus encephalitis, possible Newcastle disease, and organochlorine toxicoses at Lake Apopka in Florida. Although type C botulism had been reported in the AWPE throughout the 1980s and 90s, the botulism die-offs in AWPE and other fish-eating birds at the Salton Sea in the 1990s had a very distinct and novel epizootiology (Rocke et al. 2004).

It is also possible that the observed increase in total mortality of the AWPE reflects a relatively constant mortality rate in an increasing population. Best estimates of AWPE numbers suggest that they have increased in the Central flyway (King and Anderson 2005) and many of the larger die-offs in the 1990 s were reported from this region, particularly the loss of juveniles in breeding colonies. However in the Pacific flyway, it is thought that total numbers of birds have de- creased from historical numbers (Anderson and King, 2005), while reported mortality of the AWPE in this region has increased. There were five die-offs reported that involved ten or more birds before 1990 (594 birds estimated lost) and 19 die-offs reported after 1990 (10,047 birds estimated lost). As West Nile virus moves west through the U.S., this trend may increase. The complexity of AWPE population dynamics precludes a definitive conclusion about the increased reported losses in this species, but certainly regional differences in disease occurrence warrants a closer examination.

\section{Type C Botulism}

AWPE have died in numerous outbreaks of type C botulism since 1980 at various locations throughout the U.S. (Fig. 1), however, none were as devastating as the 1996 outbreak at Salton Sea, a large saltwater lake in southern California. Approximately 15,000 fish-eating birds died there and 8,500 were AWPE (Friend 2002; Rocke et al. 2004). This outbreak was unusual in several respects. Pri- 


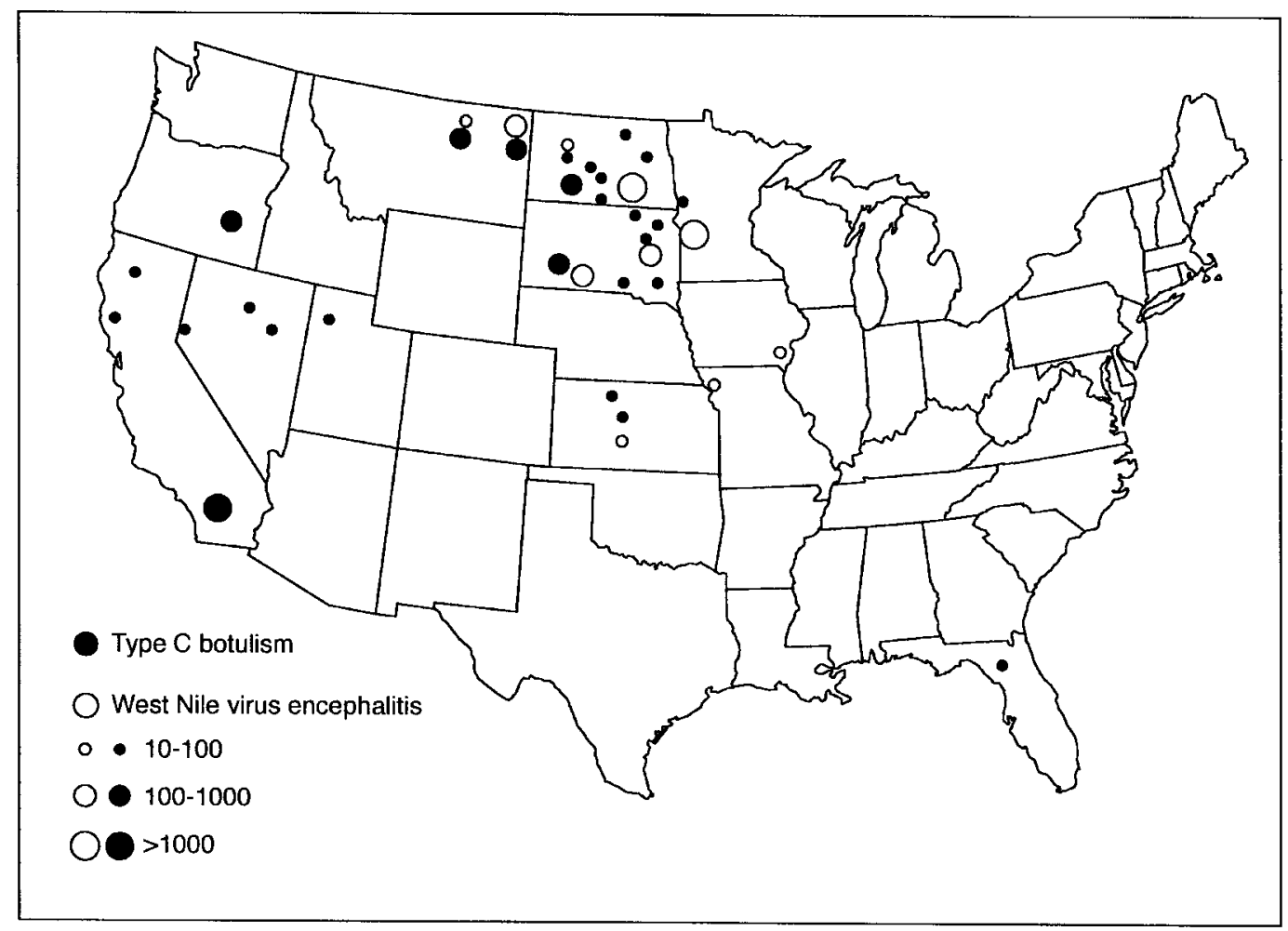

Figure 1. Locations and cumulative magnitude of die-offs from type $\mathrm{C}$ botulism and West Nile virus encephalitis involving more than ten American White Pelicans as reported to the U.S. Geological Survey, National Wildlife Health Center, 1978-2003.

or to this event, type $\mathrm{C}$ botulism in fish-eating birds in North America was considered infrequent and incidental to larger outbreaks in waterfowl that often involved death of hundreds of thousands of individuals. The largest reported loss of the AWPE from type C botulism before 1996 was 223 birds at Long Lake, North Dakota in 1988. Most previous reported botulism outbreaks that involved large numbers of fish-eating birds in North American (mostly loons and gulls) were caused by type E botulinum toxin. In the Salton Sea outbreak, fish, specifically the introduced Tilapia (Oreochromis mossambicus), which are not typically associated with type $\mathrm{C}$ botulism, were implicated as the source of toxin for birds (Rocke et al. 2004). Introduced into the Salton Sea in the 1960s, Tilapia soon became the most abundant forage fish in the sea (Dill and Cordone 1997). In 1996, the two species of pelicans were observed feeding heavily on Tilapia (D. W. Anderson, pers. comm.), and numerous sick and dead Tilapia (>50\% in some locations) were found to contain botulism toxin in their gastrointestinal tracts (Rocke et al. 2004). In addition, the 1996 dieoff at Salton Sea was the largest loss of pelicans ever reported from any disease agent in the world. It has been estimated that $15-20 \%$ of the western metapopulation of the AWPE died in this event (D. W. Anderson, pers. comm.). Smaller die-offs of both AWPE and the Brown Pelican (Pelecanus occidentalis) from type C botulism occurred at the Salton Sea in 1994 and 1995, and every year since 1996 (Fig. 2; Rocke et al. 2004). The risk of another devastating outbreak of the magnitude that occurred in 1996 is unknown but should be considered.

West Nile Virus Encephalitis

AWPE were present in many states that reported West Nile virus infections in birds 


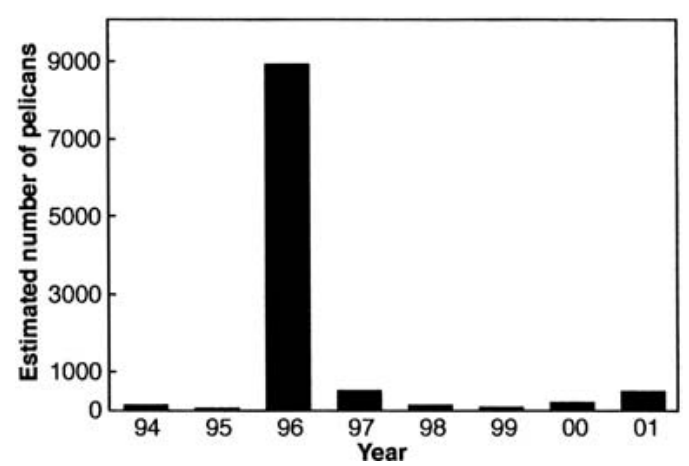

Figure 2. Estimated numbers of American White Pelicans afflicted with type $C$ botulism, 1994-2001, at the Sonny Bono Salton Sea National Wildlife Refuge. No losses were reported in 2002 and 2003.

in 2000 and 2001, but the first confirmed cases of West Nile virus encephalitis in AWPE were two young birds collected in South Dakota during July 2002. Both birds had severe encephalitis and West Nile virus was cultured from tissues. Between July 2002 and September 2003, investigations of mortality in the AWPE were conducted at eight locations in 2002 and twelve locations in 2003. West Nile virus was confirmed as the cause of death in the AWPE at nine sites where more than ten individuals died. Refuge and resource management staff in seven states reported the losses of 10-2,864. Although all of the mortality was not confirmed to be due to West Nile virus infection, at one site, up to $95 \%$ of the young of that year died and specimens submitted late in the mortality event were positive for West Nile virus. Adult AWPE were also diagnosed with West Nile virus encephalitis, but juvenile birds may be more susceptible to the virus or more exposed to mosquito-feeding because of their incomplete feather coverings, lack of preening and immobility in the nesting colonies where swarms of mosquitoes were concentrated. Young nestling birds of other species are more susceptible than adults to other arthropod-borne viruses (Holden et al. 1973) and to neurotropic Newcastle disease virus (Glaser et al. 1999). Increased susceptibility of juvenile AWPE to West Nile virus and the cause of this proposed susceptibility remain to be determined.

\section{Possible Newcastle Disease}

In the summer of 1992, neurotropic Newcastle disease caused extensive mortality in nesting colonies of the Double-crested Cormorant in seven northern states and four Canadian provinces; the disease was confirmed in individuals by virus isolation and histopathology (Glaser et al. 1999). Simultaneously, an estimated 5,000 juvenile AWPE died in North Dakota and Minnesota, with mortality rates $\geq 90 \%$ at two breeding colony sites where most of the mortality occurred (Marsh Lake, Minnesota and Chase Lake, North Dakota). Sick AWPE exhibited clinical signs similar to the sick cormorants, including unilateral or bilateral wing and leg paralysis/paresis, dropping neck, and an inability or reluctance to move (Glaser et al. 1999). Unfortunately, the virus was not isolated from any of the 24 AWPE carcasses examined despite repeated attempts, and microscopic lesions compatible with neurotropic Newcastle disease (non-suppurative encephalitis) were not found (Meteyer et al. 1997). A similar extensive epornitic of neurotropic Newcastle disease in Double-crested Cormorants occurred in Canada in 1990 and was associated with the deaths of approximately 140 AWPE; Newcastle disease virus was isolated from one AWPE carcass (Wobeser et al. 1993). The inability to isolate virus from the AWPE, despite clinical signs suggestive of Newcastle disease, makes diagnosis of these mortality events problematic.

\section{Emaciation of Unknown Etiology}

For several die-offs that involved juvenile AWPE in breeding colonies, emaciation was listed as the cause of death, but no specific etiology was found. The largest of these reports occurred at Chase Lake, North Dakota in 1993, where an estimated 4,500 AWPE chicks perished. Because the weather was unusually severe (extremely cold and windy) just prior to this event, malnutrition and hypothermia were thought to play a role in the deaths. Interestingly, similar events took place in two breeding colonies in Montana (Medicine Lake and Bowdoin NWR) and 
one in California (Klamath Basin NWR) the same year, resulting in an estimated loss of another 614 juveniles. Prior to that, 350 juvenile AWPE reportedly died at Crowley Lake, California in 1989 and starvation was thought to be the primary cause of death. A number of birds also had heavy infestations of the nematode Contracaecum in the gizzard and stomach and, in severe cases, this parasite may have contributed to emaciation. In 1990, 200 young AWPE were estimated to have died at Lac qui Parle, Minnesota, 110 near Lake Malheur, Oregon, and 80 at Chase Lake, North Dakota. In all these cases, emaciation was noted in birds submitted for examination. It is possible that disease agents may have played a role in these events, but they were not detected.

\section{Trauma}

Trauma was reported fairly frequently in the AWPE and most events were associated with hailstorms. The largest event occurred in September of 2001, when a storm near La Junta, Colorado, with hailstones 2.5-5.0 cm in diameter, reportedly killed 1,624 individuals. Hailstorms were also suspected to have killed 56 individuals in Nebraska in 1991 and 39 in Oklahoma in 1995. Powerline collision was implicated as the cause of death of 35 AWPE in Iowa in 1989. Twenty AWPE were reportedly shot in Nevada in 2000 and 32 were found dead in 1990 in a field in Texas with signs of trauma, but the source of their injuries could not be determined.

\section{Toxicoses}

The only significant reported mortality in the AWPE caused by chemical toxins occurred in 1999 in the Lake Apopka region, located in northwest Orange and southeast Lake counties of Florida (Industrial Economics 2003). An estimated 1,000 AWPE died in the vicinity of the lake and most individuals examined had toxic levels of organochlorine pesticides in their tissues, including dieldrin, endrin, and chlordane, presumably after ingestion of contaminated fish. The contamination resulted from the flooding of former vegetable farms where fertilizer and pesticide use had been extensive prior to their conversion to public ownership. The water has since been drained from the former farms to discourage their use by fish-eating birds.

\section{Miscellaneous}

Surprisingly, avian cholera, an infectious bacterial disease that afflicts numerous waterbirds every year in the U.S., has not been an appreciable problem for the AWPE to date. Approximately 132 AWPE have been reported dead in four outbreaks which occurred at Salton Sea in southern California in 1998, 1999 and 2000 and at Stillwater NWR, Nevada in 1987. A recent die-off of approximately 120 AWPE at La Creek NWR, South Dakota (2001) was thought to have been caused by another infectious bacterial disease, chlamydiosis. Lesions evident on necropsy, special stains for histologic evidence of chlamydia-like organisms in formanlinized tissue, and polymerase chain reaction results from assays performed on tissues from affected birds suggested the presence of Chlamydia psittaci as the causative agent. However, the bacteria could not be isolated. Aspergillosis, an infectious fungal disease of waterbirds, was reported to have killed 24 AWPE in Florida in 2000.

\section{ACKNOWLEDGMENTS}

We gratefully acknowledge the efforts of many field personnel who submitted carcasses as well as the diagnostic laboratories whose many staff conducted postmortem examinations and conducted diagnostic tests over the 25 years included in this review. We also thank NWHC personnel who updated and maintained files of epizootics in wildlife. Critical review of the manuscript was provided by C. Brand and M. Fleischli.

\section{Literature Cited}

Anderson, D. W. and D. T. King. 2005. Introduction: Biology and conservation of the American White Pelican. Waterbirds 28 (Special Publication 1): 1-8.

Belisle, A. A. and D. M. Swineford. 1988. Simple, specific analysis of organophosphorus and carbamate pesticides in sediments using column extraction and gas chromatography. Environmental Toxicology and Chemistry 7: 749-752.

Blus, L., C. J. Henny and R. A. Grove. 1989. Rise and fall of endrin usage in Washington State fruit orchards: effects on wildlife. Environmental Pollution 60: 331-349. 
Boyer, K. W. 1984. Metals and other elements at trace levels in foods. Pages 444-476 in S. Williams (Ed.), Official methods of analysis of the Association of Official Analytical Chemists, 14th edition. Association of Official Analytical Chemists, Inc., Arlington.

Cromartie, E., W. L. Reichel, L. N. Locke, A. A. Belisle, T. E. Kaiser, T. G. Lamont, B. M. Mulhern, R. M. Prouty and D. M. Swineford. 1975. Residues of organochlorine pesticides and polychlorinated biphenyls and autopsy data for bald eagles, 1971-1972. Pesticides Monitoring Journal 9: 11-14.

Dieter, M. P. and J. L. Ludke. 1975. Studies on combined effects of organophosphates and heavy metals in birds. I. Plasma and brain cholinesterase in coturnix quail fed methyl mercury and orally dosed with parathion. Bulletin of Environmental Contamination and Toxicology 13: 257-262.

Dill, W. A. and A. J. Cordone. 1997. History and status of introduced fishes in California, 1871-1996. California Department of Fish and Game Bulletin 178.

Docherty, D. E and P. G. Slota. 1988. Use of Muscovy duck embryo fibroblasts for the isolation of viruses from wild birds. Journal of Tissue Culture Methods 11: 165-170.

Ellman, G. L., K. D. Courtney, V. Andres, Jr. and R. M. Featherstone. 1961. A new and rapid colorimetric determination of acetylcholinesterase activity. Biochemistry and Pharmacology 7: 88-95.

Friend, M. 2002. Avian Disease at the Salton Sea. Hydrobiologia 473: 293-306.

Friend, M., R. G. McLean and F. J. Dein. 2001. Disease emergence in birds: challenges for the twenty-first century. Auk 118: 290-303.

Glaser, L. C., I. K. Barker, D. V. C. Weseloh, J. P. Ludwig, R. M. Windingstad, D. W. Key and T. K. Bollinger. 1999. The 1992 epizootic of Newcastle disease in double-crested cormorants in North America. Journal of Wildlife Diseases 35: 319-330.

Hill, E. F. 1988. Brain cholinesterase activity of apparently normal wild birds. Journal of Wildlife Diseases 24: 51-61.

Hill, E. F. and W. J. Fleming. 1982. Anticholinesterase poisoning of birds: field monitoring and diagnosis of acute poisoning. Environmental Toxicology and Chemistry 1: 27-38.

Holden, P., D. B. Francy, C. J. Mitchell, R. O. Hayes, J. S. Lazuick and T. B. Hughes. 1973. House sparrows, Passer domesticus (L.), as hosts of arboviruses in Hale County, Texas. II. Laboratory studies with western equine encephalitis virus. The American Journal of Tropical Medicine and Hygiene 22: 254-262.

Industrial Economics. 2003. Lake Apopka Natural Resource Damage Assessment and Restoration Plan. U.S. Fish and Wildlife Service and St. Johns River Management District, Florida.

King, D. T. 2005. Interactions between the American White Pelican and aquaculture in the southeastern
United States: an overview. Waterbirds 28 (Special Publication 1): 83-86.

Komar, N. 2003. West Nile virus: epidemiology and ecology in North America. Advances in Virus Research 61: 185-234

Krynitsky, A. J. 1987. Preparation of biological tissue for determination of arsenic and selenium by graphite furnace atomic absorption spectrometry. Analytical Chemistry 59: 1884-1886.

Meteyer, C. U., D. E. Dougherty, J. C. Franson, M. Samuel, D. A. Senne and L. C. Glaser. 1997. Diagnostic findings in the 1992 epornitic of neurotropic velogenic Newcastle Disease in Double-crested Cormorants. Avian Diseases 41: 171-180.

Quortrup, E. R. and R. L. Sudheimer. 1943. Detection of botulinus toxin in the bloodstream of wild ducks. Journal of the American Veterinary Medical Association 102: 264-266.

Rocke, T. E., S. R. Smith and S. W. Nashold. 1998. A simple in-vitro test for the diagnosis of type $\mathrm{C}$ botulism in wild birds. Journal of Wildlife Diseases 34: 744-751.

Rocke, T. E., P. Nol, C. Pelliza and K. Sturm. 2004. Type $\mathrm{C}$ botulism in pelicans and other fish-eating birds at the Salton Sea, California, 1994-2001. Studies in Avian Biology 27: 136-140.

Senne, D. A. 1989. Virus propagation in embryonating eggs. Pages 176-181 in H. G. Purchase, L. H. Arp, C. H. Domermuth and J. E. Pearson (Eds.), A laboratory manual for the isolation and identification of avian pathogens. Kendall/Hunt Publishing Company, Dubuque, Iowa.

Smith, M. R., N. J. Thomas and C. Hulse. 1995. Application of brain cholinesterase reactivation to differentiate between organophosphorus and carbamate pesticide exposure in wild birds. Journal of Wildlife Diseases 31: 263-267.

Stickel, W. H., L. F. Stickel and J. W. Spann. 1969. Tissue residues of dieldrin in relation to mortality in birds and mammals. Pages 174-204 in M. W. Miller and G. G. Berg (Eds.), Chemical fallout: current research on persistent pesticides. Charles C. Thomas, Springfield, Illinois.

Stickel, W. H., W. L. Reichel and D. L. Hughes. 1979a. Endrin in birds: lethal residues and secondary poisoning. Pages 397-406 in W.B. Deichman (Ed.), Toxicology and occupational medicine. Elsevier, North Holland, New York.

Stickel, L. R., W. H. Stickel, R. A. McArthur and D. L. Hughes. 1979b. Chlordane in birds: a study of lethal residues and loss rates. Pages 387-396 in W. B. Deichman (Ed.), Toxicology and occupational medicine. Elsevier, North Holland, New York.

Wobeser, G. A., F. A. Leighton, R. Norman, D. J. Neyers, D. Onderka, M. J. Pybus, J. L. Neufeld, G. A. Fox and D. J. Alexander. 1993. Newcastle disease in wild water birds in western Canada, 1990. Canadian Veterinary Journal 34: 353-359. 